\title{
Review Article \\ Herbal Remedy: An Alternate Therapy of Nonsteroidal Anti-Inflammatory Drug Induced Gastric Ulcer Healing
}

\author{
Ananya Chatterjee and Sandip K. Bandyopadhyay \\ Department of Biochemistry, KPC Medical College \& Hospital, Jadavpur, Kolkata 700032, India \\ Correspondence should be addressed to Sandip K. Bandyopadhyay; sandipkpc@gmail.com
}

Received 27 October 2013; Revised 1 April 2014; Accepted 15 April 2014; Published 6 May 2014

Academic Editor: Tomasz Brzozowski

Copyright ( 2014 A. Chatterjee and S. K. Bandyopadhyay. This is an open access article distributed under the Creative Commons Attribution License, which permits unrestricted use, distribution, and reproduction in any medium, provided the original work is properly cited.

\begin{abstract}
Nonsteroidal anti-inflammatory drugs (NSAIDs) are one of the most commonly used therapeutic drug groups used worldwide for curing an array of health problems like pain, inflammation, cardiovascular complications, and many other diseases, but they may cause different side effects including gastroduodenal disorders. So, there is a growing interest and need to search for nontoxic, antiulcer formulations from medicinal plants to treat NSAIDs induced gastric ulcer. Extensive research has reported on many natural plants like Camellia sinensis, Phyllanthus emblica, Myristica malabarica, Piper betle, Picrorhiza kurroa, and so forth, and their active constituents reduced NSAIDs induced gastric ulcer via their antioxidative as well as immunomodulatory activity. Therefore, use of herbal formulations in daily life may prevent NSAIDs induced gastric ulceration and other side effects.
\end{abstract}

\section{Introduction}

India has immeasurable varieties of tropical plants. Native Indians possess a long tradition of Kabiraji medicine utilizing such medicinal plants. The Indian Medicine Central Council Act 1970 recognizes Ayurvedic medicine. The World Health Organization also sponsors and encourages research in Ayurvedic treatments [1]. The use of herbal medicine can be traced back to China about 5000 years ago. Extracts of several plants have been used as therapeutic agents for many diseases by virtue of their antioxidant actions. Spices and herbs are recognized sources of natural antioxidants, many of which are phenols and aromatic amines. These can act at different levels by decreasing local oxygen concentrations, decreasing superoxide formation, preventing chain initiation, metal-induced free radical generation, and lipid peroxidation. However, despite the large varieties of such plants grown in India, a minimal number has been thoroughly studied for all aspects of their potential therapeutic value in medicine. A growing body of evidence suggests that at least part of the therapeutic values may be contributed by their antioxidative property. These natural antioxidants may therefore contribute to protect the human body from several diseases [2] including gastric ulcer.

Clinical research has confirmed the efficacy of several medicinal plants for the treatment of gastric disorders, and basic scientific research has uncovered many of the mechanisms to explain their therapeutic effects $[3,4]$.

Gastric ulcer is a common disease, where the gastric mucosa get damaged and perforations lead to bleeding. A report of the Indian Council of Medical Research on the epidemiology of gastric ulcer in India showed that the overall prevalence rate of the disease ranged from 1 to 6.5 per thousand in the age group of 15 years and above in a selected urban population. Mahadeva and Goh have extensively studied and reported the epidemiology of this disease [5].

A number of factors are responsible for this gastric ulcer disease of which $70 \%$ to $80 \%$ are due to infection of Helicobactor pylori, a spiral shaped, gram negative bacteria [6-8]. However, the use of nonsteroidal anti-inflammatory drugs (NSAIDs) accounts for approximately 25\% of gastric ulcer cases with an upward trend [9]. The NSAIDs are one of the most widely prescribed drugs in the world and are extensively used to alleviate clinical cases specially for pain 
and inflammation [10]. However, these drugs are well-known to induce stomach ulceration and delay ulcer healing [11]. Despite recent advances, an adequate remedy for the NSAIDinduced gastropathy remains elusive. The World Health Organization has stressed the need to develop drugs from plant origin, which will be inexpensive, accessible particularly to the rural people in the developing countries, and show less/no side effects.

Therefore, development of a drug having antiulcerogenic property from plant sources without compromising the efficacy and safety would be expected to benefit millions of suffering humanity.

\section{Review of the Literature}

In the first century A.D., Dioscorides wrote De Materia Medica, a medicinal plant catalog which became the prototype for modern pharmacopoeias. Of the estimated 250,000 to 500,000 species of plants on Earth, merely $10 \%$ are used for medicinal purposes [12]. However, not all medicinal plants are devoid of side effects. In this context, Holmes wrote, "If the whole materia medica as now used could be sunk to the bottom of the sea, it would be all the better for mankind-and all the worse for the fishes."

Application of herbal medicine dates back to China for almost about 5000 years ago. Extracts of various plants have applications as therapeutic agents for certain diseases because they possess antioxidant activities. Spices and herbs are well-known for their natural antioxidants properties, most of which happen to be phenols and aromatic amines. Their activities may vary at different levels by decreasing local oxygen concentrations, decreasing superoxide formation, preventing chain initiation, metal-induced free radical generation as well as lipid peroxidation. These antioxidants may therefore protect the human body from several diseases [2].

The importance of ethnopharmacological studies is emphasized by the observation that the first effective drug against gastric ulcer was carbenoxolone, isolated from the plant, Glycyrrhiza glabra. Likewise, gefarnate is also developed from cabbage, which has been employed as an antiulcer agent in folk medicine $[13,14]$. Hence, a search among medicinal plants has become imperative despite the progress and approaches in conventional chemistry and pharmacology in producing effective drugs.

\section{Brief Note on NSAIDs and Gastric Ulcer}

Nonsteroidal anti-inflammatory drugs (NSAIDs) are wellknown analgesic and antipyretic drugs.

NSAIDs like aspirin, indomethacin, ibuprofen, naproxen, and so forth are usually used for the treatment of pain, inflammation, colorectal cancer, cancer, cardiovascular disease, rheumatoid arthritis, osteoarthritis, inflammatory arthropathies (e.g., ankylosing spondylitis, psoriatic arthritis, and Reiter's syndrome), and so many cases. Some of the commonly used anti-inflammatory drugs and their mechanism of action are listed in Table $1[15,16]$.
But long term use of such pain killers ultimately causes a significant gastroduodenal risk. Among the total gastric ulcer patients, $25 \%$ are suffering from NSAID induced gastric ulcer and this account increased day by day.

NSAIDs have an effect on the gastroduodenal barrier at the epithelial level, intraepithelial level, and subepithelial level. At the epithelial level, it reduces the synthesis and the secretion of mucus and makes the proteolytic action of pepsins. This changes the viscosity and electric capacity of the mucus, favoring the back diffusion of ions. At the intraepithelial level, it causes epithelial denudation due to direct cellular damage, since ionized NSAIDs stay trapped inside the epithelium. At the subepithelial level, it leads to thrombosis in the microcirculation and vasoconstriction of the arterioles of the submucosa.

\section{Mechanism of Action of NSAIDs in the GI Tract (Figure 1)}

4.1. Oxidative Stress. NSAIDs mediated gastric lesions accompanied by oxidative damage. Oxidative stress refers to a situation of serious imbalance between production of reactive oxygen/reactive nitrogen species (ROS/RNS) and antioxidant defence. This is manifested from diminished antioxidants, mutations affecting antioxidant defence enzymes, or increased production of ROS/RNS and is induced by various endogenous and exogenous factors. This leads to extensive damage to key biomacromolecules leading to various diseases including gastric ulceration. It is now established that neutrophil infiltration, generation of ROS [17], cytokine imbalance, and initiation of lipid peroxidation play significant roles in the pathogenesis of peptic ulcer.

4.2. Prostaglandin Synthesis Inhibition. Prostaglandins (PGs) are 20-carbon fatty acids produced by the cyclooxygenase (COX)-catalyzed reaction of arachidonic acid. But most of the NSAIDs are nonspecific cyclooxygenase blockers. They block both constitutive COX-1 and inducible COX-2, ultimately hampering the synthesis of PGs. PGs generally act in an autocrine or paracrine manner. These appear to exert their cytoprotective action by stimulating mucus and bicarbonate secretion, maintaining mucosal blood flow and enhancing the resistance of epithelial cells to injury induced by cytotoxins [18]. PGs can suppress the generation of reactive oxygen metabolites produced by neutrophils thereby reducing inflammation and tissue injury [19]. Further, PGs also contribute to ulcer healing by inducing angiogenesis [20]. There has been accumulating evidence that PG might contribute to ulcer healing by maintaining the balance between the proangiogenic and antiangiogenic factors [21].

4.3. Nitrogen Metabolizing Enzymes. Nitric oxide (NO) is one of the main mediators of gastrointestinal mucosal defense but, in contradiction, it also contributes to mucosal damage depending upon the concentration of NO [22].

It is seen that endothelial nitric oxide synthase (e-NOS) isoform of constitutive NOS produces low amounts of NO. In contrast, the inducible form of NOS (iNOS) produces 
TABLE 1: The common nonsteroidal anti-inflammatory drugs (NSAIDs) and their mechanism of action $[15,16]$.

\begin{tabular}{lll}
\hline Serial no. & Drug & Mechanism of action \\
\hline 1 & Indomethacin & $\begin{array}{l}\text { Nonselective COX inhibitor, also inhibits phospholipase A and C, reduces } \\
\text { neutrophil migration, and reduces T and B cell proliferation } \\
\text { Irreversibly inhibits COX }\end{array}$ \\
3 & Aspirin & Nonselective COX inhibitor \\
4 & Diclofenac & Nonselective COX inhibitor \\
5 & Ibuprofen & Nonselective COX inhibitor \\
6 & Naproxen & Nonselective COX and lipoxygenase inhibitor \\
7 & Ketoprofen & Selective COX-2 inhibitor \\
8 & Celecoxib & Preferentially inhibits COX-2, also inhibits COX-1 and thromboxaneA 2 \\
9 & Meloxicam & Nonselective COX inhibitor \\
10 & Diflunisal & Nonselective COX inhibitor \\
11 & Etodolac & Nonselective COX inhibitor, affects TNF- $\alpha$ and nitric oxide synthesis \\
12 & Flurbiprofen & Nonselective COX inhibitor \\
13 & Oxaprozin & Nonselective COX inhibitor \\
15 & Nabumetone & Nonselective COX inhibitor, also inhibits polymorphonuclear leukocyte \\
& Piroxicam & migration, decreases oxygen radical production, and inhibits lymphocyte \\
\end{tabular}

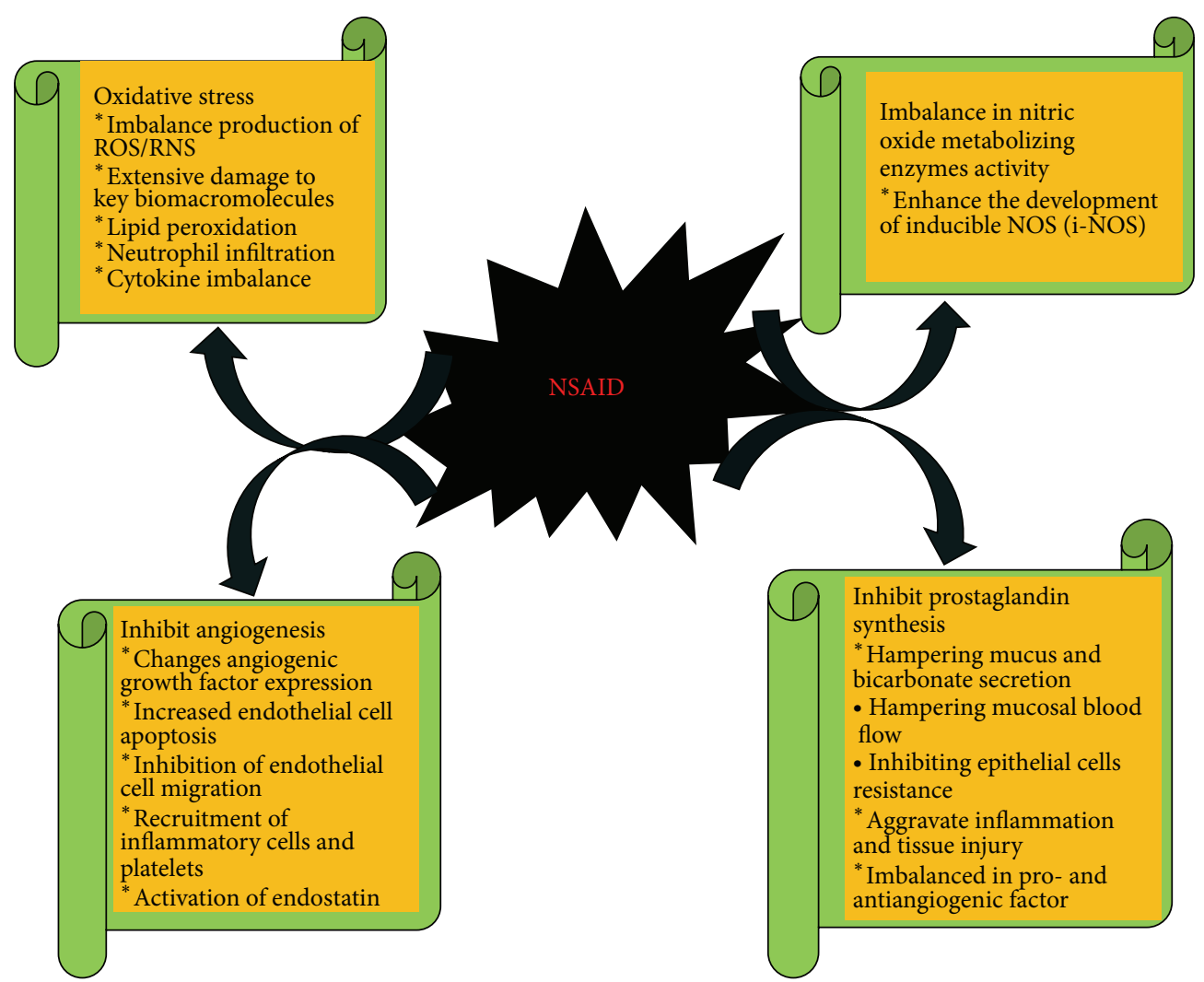

FIGURE 1: Schematic presentation of mode of action of NSAIDs.

NO in higher quantities [23]. Piotrowski et al. showed that indomethacin induced gastric ulceration gives a 12 -fold increase in gastric epithelial expression of iNOS activity compared with controls which is correlated with the damage of epithelium [24], whereas Wallace and Miller showed that NO mediates a critical role in modulation of several components of mucosal defense, including increased gastric blood flow, reduced neutrophil adhesion, and increased mucus secretion [25].

4.4. Inhibition of Angiogenesis. Besides causing gastric ulceration [26], NSAIDs often delay healing of existing ulcers 
[27-29]. Based on the experimental data and the literature, the mechanisms by which NSAIDs inhibit angiogenesis appear to be multifactorial and likely include local changes in angiogenic growth factor expression, alteration in key regulators and mediators, increased endothelial cell apoptosis, inhibition of endothelial cell migration, recruitment of inflammatory cells and platelets, and/or thromboxane A2 mediated effects as well as activation of endostatin [30]. It has been observed that inhibition of angiogenesis by NSAIDs involves interference with MAP kinase activity and its nuclear translocation [31].

4.5. Helicobacter pylori (H. pylori) and NSAIDS. Helicobacter pylori (H. pylori) and NSAIDs both are the most common causative factors of gastroduodenal ulcer in animals and humans. Their relationship in ulcerogenesis has been little studied [32]. According to some reports, their synergistic or antagonistic action on the gastric mucosa has been a subject of controversy [33]. Accumulated evidence in humans and animals shows that both NSAID (aspirin) and H. pylori upregulate the expression of cyclooxygenase (COX)-2 both at mRNA and protein levels at the ulcer margin but failed to influence significantly that of COX-1 [33]. It was, therefore, proposed that $H$. pylori may in fact antagonize aspirininduced delay of ulcer healing due to suppression of acid secretion, enhancement of PGE2 synthesis and overexpression of growth factors such as TGF- $\alpha$ and VEGF [33].

\section{Therapy of Gastric Ulcer}

Specific treatment for stomach and duodenal ulcers is decided by the physician on the basis of patient's age, overall health, medical history, extent of the pathogenesis, tolerance for medications, procedures, or therapies, and expectations or preference. Besides, personal factors such as smoking, caffeine, alcohol, stress, secretion of acid and pepsin, and so forth are suspected to play a role in the development of stomach or duodenal ulcers. Hence, the simplest treatment involving lifestyle changes namely abstinence from smoking and alcohol and over stress in many cases.

Earlier, the major approach towards therapy was targeted to reduce the secretion of gastric acids, which were considered as the sole cause of ulcer formation. Now, the treatment modality has changed to potentiating of the mucosal defense along with reduction of acid secretion [21]. The treatment of peptic ulcer is often designed with single or combination drugs. The medical support is designed either singly or in combination by blocking the receptor sites, for example, with a $\mathrm{H}_{2}$ receptor antagonist, inhibition of intracellular mechanism involving calcium and/or c-AMP, protection of gastric mucosa (cytoprotective function) from chemically induced injury, $\mathrm{H}^{+} \mathrm{K}^{+}$-ATPase, inhibition of terminal step of acid secretion, and eradication of $H$. pylori infection. For very severe conditions, standard open surgery is the only method available at present.

The most commonly used drugs include antibiotics to kill $H$. pylori (triple therapy), acid blockers (cimetidine, ranitidine, or famotidine), proton pump inhibitors (omeprazole), and tissue lining protecting agents (sucralfate). A brief account of these is presented in Table 2.

The commonly available synthetic antiulcer drugs are associated with various side effects as described in Table 2. These drugs have decreased the morbidity rates but produce many adverse effects including relapse of the disease and are often expensive for the poor populations. Different studies have confirmed that all the NSAIDs do not have the same capacity to induce gastric ulcer. Thus, a mechanistic approach of drug development might provide new NSAIDs that are clinically effective and safer to use. In recent days, NO-NSAIDs and H2S-NSAIDs are investigated as potential alternative to NSAIDs. Nitric oxide (NO)-NSAIDS is a new class of compounds. They are synthesized by ester linkage of an NO-releasing moiety to conventional NSAIDS, such as aspirin (NO-aspirin), flurbiprofen (NO-flurbiprofen), naproxen (NO-naproxen), diclofenac (Nitrofenac), lbuprofen (NO-lbuprofen), and indomethacin (NO-indomethacin) [34]. NO-NSAID unlike classic NSAIDs does not affect gastric mucosa and fails to delay the healing of preexisting ulcers [35]. This novel group of compounds reduced gastrointestinal toxicity by enhancing vasodilatation of the gastric vasculature, inhibition of leukocyte adhesion, and inactivation of caspase activity [34]. Like the NO-NSAIDs, hydrogen sulfide $\left(\mathrm{H}_{2} \mathrm{~S}\right)$ releasing NSAIDs is another newly synthesized compound. $\mathrm{H}_{2} \mathrm{~S}$ is potent vasodilatory agent that couples with NSAIDs to generate new classes of antiinflammatory and analgesic agents with the potential to spare the gastrointestinal and cardiovascular system [36]. Either naproxen or diclofenac coupled with an $\mathrm{H}_{2} \mathrm{~S}$ releasing moiety has been reported to cause less gastrointestinal and cardiovascular injury than parent NSAIDs in preclinical models [36]. On the other hand, some reports also showed that coupling of $\mathrm{H}_{2} \mathrm{~S}$ releasing moiety with NSAID may not be safe because $\mathrm{H}_{2} \mathrm{~S}$ also acts as a proinflammatory agent [37] and the dose of $\mathrm{H}_{2} \mathrm{~S}$ is very critical, a higher dose may even cause death [38].

Therefore, the search for non- or less-toxic yet equally efficacious drugs sourced from nature is an area of intense research. Moreover, in view of the recent global economic liberalization and compulsion under GATT, a new initiative for the development of phytomedicine of Indian origin has now been taken.

India is a megadiverse country possessing a wide variety of plants with their medicinal properties well documented in ancient Indian literature. Many compounds derived from natural sources have pharmacological activities and may thus have immense potential for future drug development. Plantderived products are an attractive option because they are cheap, easily available, and relatively less toxic.

\section{Antiulcer Drugs of Herbal Origin}

The herbal and other indigenous sources have not adequately been explored for the presence of safe and effective antiulcer drugs. Though certain plants and their purified constituents have been reported to possess significant antiulcer potential 
TABLE 2: Some of the market available synthetic antiulcer drugs and their mode of action are summarized in Table 2 (http://www .wikipedia.com).

\begin{tabular}{|c|c|c|c|c|}
\hline Sl. no. & Synthetic drug & $\begin{array}{c}\text { Data bank } \\
\text { (accession number) }\end{array}$ & Acts as & Mode of action \\
\hline 1 & Omeprazole & DB00338 & $\begin{array}{l}\text { Proton } \\
\text { pump inhibitor }\end{array}$ & $\begin{array}{l}\text { Proton pump inhibitor that suppresses gastric acid } \\
\text { secretion by specific inhibition of the } \mathrm{H}^{+} / \mathrm{K}^{+} \text {-ATPase in } \\
\text { the gastric parietal cell. Omeprazole blocks the final } \\
\text { step in acid production, thus reducing gastric acidity. }\end{array}$ \\
\hline 2 & Misoprostol & DB00929 & $\begin{array}{l}\text { Proton } \\
\text { pump inhibitor }\end{array}$ & $\begin{array}{l}\text { A synthetic analog of natural prostaglandin E1. It } \\
\text { produces a dose-related inhibition of gastric acid and } \\
\text { pepsin secretion and enhances mucosal resistance to } \\
\text { injury. It is an effective antiulcer agent and also has } \\
\text { oxytocic properties. }\end{array}$ \\
\hline 3 & Pantoprazole & DB00213 & $\begin{array}{l}\text { Proton } \\
\text { pump inhibitor }\end{array}$ & $\begin{array}{l}\text { Pantoprazole is a proton pump inhibitor (PPI) that } \\
\text { suppresses the final step in gastric acid production by } \\
\text { forming a covalent bond to two sites of the }\left(\mathrm{H}^{+} \text {, }\right. \\
\mathrm{K}^{+} \text {)-ATPase enzyme system at the secretory surface of } \\
\text { the gastric parietal cell. }\end{array}$ \\
\hline 4 & Lansoprazole & DB00448 & $\begin{array}{l}\text { Proton } \\
\text { pump inhibitor }\end{array}$ & $\begin{array}{l}\text { Lansoprazole belongs to a class of antisecretory } \\
\text { compounds, the substituted benzimidazoles, that do } \\
\text { not exhibit anticholinergic or histamine } \mathrm{H}_{2} \text {-receptor } \\
\text { antagonist properties, but rather suppress gastric acid } \\
\text { secretion by specific inhibition of the }\left(\mathrm{H}^{+}, \mathrm{K}^{+}\right) \text {-ATPase } \\
\text { enzyme system at the secretory surface of the gastric } \\
\text { parietal cell. }\end{array}$ \\
\hline 5 & Esomeprazole & DB00736 & $\begin{array}{l}\text { Proton } \\
\text { pump inhibitor }\end{array}$ & $\begin{array}{l}\text { Esomeprazole is a proton pump inhibitor that } \\
\text { suppresses gastric acid secretion by specific inhibition } \\
\text { of the } \mathrm{H}^{+} / \mathrm{K}^{+} \text {-ATPase in the gastric parietal cell. By } \\
\text { acting specifically on the proton pump, esomeprazole } \\
\text { blocks the final step in acid production, thus reducing } \\
\text { gastric acidity. }\end{array}$ \\
\hline 6 & Rabeprazole & DB01129 & $\begin{array}{l}\text { Proton } \\
\text { pump inhibitor }\end{array}$ & $\begin{array}{l}\text { Rabeprazole belongs to a class of antisecretory } \\
\text { compounds (substituted benzimidazole proton-pump } \\
\text { inhibitors) that do not exhibit anticholinergic or } \\
\text { histamine } \mathrm{H}_{2} \text {-receptor antagonist properties, but } \\
\text { suppress gastric acid secretion by inhibiting the gastric } \\
\mathrm{H}^{+} / \mathrm{K}^{+} \text {ATPase Rabeprazole blocks the final step of } \\
\text { gastric acid secretion. }\end{array}$ \\
\hline 7 & Sucralfate & DB00364 & $\begin{array}{l}\text { In acidic environment } \\
(\mathrm{pH}<4) \text { reacts with } \\
\text { hydrochloric acid in } \\
\text { the stomach acting as } \\
\text { an acid buffer }\end{array}$ & $\begin{array}{l}\text { Although sucralfate's mechanism is not entirely } \\
\text { understood, there are several factors that most likely } \\
\text { contribute to its action. In the presence of stomach acid } \\
\text { and binds bile salts coming from the liver via the bile } \\
\text { thus protecting the stomach lining from injury caused } \\
\text { by the bile acids. Sucralfate may increase prostaglandin } \\
\text { production. }\end{array}$ \\
\hline 8 & Cimetidine & DB00501 & $\begin{array}{l}\text { Histamine } \\
\mathrm{H}_{2} \text {-receptor } \\
\text { antagonists }\end{array}$ & $\begin{array}{l}\text { Cimetidine binds to an } \mathrm{H}_{2} \text {-receptor located on the } \\
\text { basolateral membrane of the gastric parietal cell, } \\
\text { blocking histamine effects. This competitive inhibition } \\
\text { results in reduced gastric acid secretion and a reduction } \\
\text { in gastric volume and acidity. }\end{array}$ \\
\hline 9 & Ranitidine & DB00863 & $\begin{array}{l}\text { Histamine } \\
\mathrm{H}_{2} \text {-receptor } \\
\text { antagonists }\end{array}$ & $\begin{array}{l}\text { The } \mathrm{H}_{2} \text { antagonists are competitive inhibitors of } \\
\text { histamine at the parietal cell } \mathrm{H}_{2} \text {-receptor. They suppress } \\
\text { the normal secretion of acid by parietal cells and the } \\
\text { meal-stimulated secretion of acid. }\end{array}$ \\
\hline 10 & Famotidine & DB00927 & $\begin{array}{l}\text { Histamine } \\
\mathrm{H}_{2} \text {-receptor } \\
\text { antagonists }\end{array}$ & $\begin{array}{l}\text { Famotidine binds competitively to } \mathrm{H}_{2} \text {-receptors located } \\
\text { on the basolateral membrane of the parietal cell, } \\
\text { blocking histamine affects. This competitive inhibition } \\
\text { results in reduced basal and nocturnal gastric acid } \\
\text { secretion and a reduction in gastric volume, acidity, and } \\
\text { amount of gastric acid released in response to stimuli } \\
\text { including food, caffeine, insulin, betazole, or } \\
\text { pentagastrin. }\end{array}$ \\
\hline
\end{tabular}


during the last three decades, the studies have not been carried forward to a logical conclusion for establishing their clinical usefulness as has been done for various modern drugs like $\mathrm{H}_{2}$ receptor antagonists and proton pump inhibitors.

An attempt has therefore been made to summarize some important studies on the antiulcer potential of herbal drugs which may provide some clues in undertaking this challenging task of finding out a safe and promising drug from natural sources. This review includes the studies of some of plants which have a beneficial role against NSAID induced gastric ulceration and are listed as follows.

6.1. Anthocyanosides. Anthocyanosides, obtained from Vaccinium myrtillus, exert a significant preventive and curative antiulcer activity. It influences biosynthesis of the mucopolysaccharides, thus improving the efficiency of the mucus barrier at the gastric level $[39,40]$.

6.2. Apium graveolens. It is a plant species in the family Apiaceae commonly known as celery. An ethanol extract of celery is also used as a drug against gastric ulcer on rats. It was shown by Al-Howiriny et al., at the dose of 250 and $500 \mathrm{mg} / \mathrm{kg}$ body weight, that ethanolic extract of celery showed antigastric ulcer activity against indomethacin, cytodestructive agents (80\% ethanol, $0.2 \mathrm{M} \mathrm{NaOH}$, and $25 \%$ $\mathrm{NaCl}$ ), and cold restraint stress induced ulceration on rats. Apium graveolens extract significantly protects the gastric mucosa and suppresses the basal gastric secretion in rats, through its antioxidant potential [41]. In animals, bilberry decreased the incidence and severity of experimentally induced ulcers [40].

6.3. Bupleurum falcatum. B. falcatum is a species of flowering plant in the Apiaceae family. The roots of B. falcatum have been used clinically in Chinese and Japanese herbal medicine (kampo medicine). Shibata et al. [42] have reported that a crude saponin fraction of $B$. falcatum showed weak antiulcerogenic activity in pylorus ligated ulcer model. Yamada et al. [43] found that the polysaccharide fraction of B. falcatum possesses potent antiulcer activity against $\mathrm{HCl} /$ ethanolinduced lesions in mice.

6.4. Curcuma longa. Itis a perennial herb from Zingiberaceae family, distributed native to India and Southeast Asia. It has extensively been used in medicine. Curcumin, an active component of Curcuma, showsanti-inflammatory and antioxidant properties. On the basis of its antioxidant property it scavenges reactive oxygen species and regulates MMP activity to exert antiulcer activity [44]. Curcumin (diferuloylmethane), a yellow pigment in turmeric Curcuma longa, is used widely as a spice in Indian and Thai cuisine. It exhibits a number of pharmacological effects including anti-inflammatory activity, induced by suppression of PG synthesis [45]. Turmeric root extract has been found to relieve pain from biliary dyskinesia during a double-blinded study [46] and improve endoscopic healing of peptic ulcers as well as symptoms of patients with nonulcer dyspepsia [47]. There is currently much interest in its potential as a selective COX-2 inhibitory agent [48].

6.5. Camellia sinensis. It is the most popular nonalcoholic beverage worldwide. Extensive work has been carried out regarding various medicinal attributes of green tea. The prophylactic action of the tea seed-derived triterpene saponins against ethanol-induced gastric mucosal lesions $[49,50]$ and black tea extract against various ulcerogens [51,52] has been reported in rat models. Theaflavin (TF) is a major active component of black tea. TF healed indomethacin induced gastric ulcer by its antioxidative properties, synthesis of PGE2 and enhancement of mucin secretion. TF also helps to suppress various inflammatory modulators in ulcer margin [53]. eNOS modulation may be another possible pathway of gastric ulcer healing by $\mathrm{TF}$ [53].

6.6. Glycyrrhiza glabra. Liquorice or licorice is the root of Glycyrrhiza glabra from which a somewhat sweet flavour can be extracted. The liquorice plant is a legume (related to beans and peas) that is native to southern Europe and parts of Asia. It is placed under the family Fabaceae. It is a herbaceous perennial, growing to $1 \mathrm{~m}$ in height. In north India it is known as "Mulaithi." The root of G. glabra is known as licorice used for the treatment of gastric ulcer in Europe. It had been reported that licorice derived compounds elevate the prostaglandin level and promote the mucus secretion from the stomach, increase the life span of surface cell of stomach, and had an antipepsin activity which ultimately leads to ulcer healing [54]. Extracts of licorice have demonstrated the ability to accelerate the healing of gastrointestinal ulceration (especially in the stomach and esophagus) possibly due to its antioxidant effect. The antiulcer drug carbenoxolone, a succinate derivative of glycerrhetinic acid, was developed in London in the early 1960s and has become the preferred form of licorice used to promote healing of ulcers [55-57].

6.7. Kochia scoparia. Saponins isolated from the fruit of Kochia scoparia have been demonstrated to possess gastroprotective properties [58]. Its gastroprotective action is believed to be via activation of mucous membrane protective factors [59] rather than inhibition of gastric acid secretion.

6.8. Lagenaria vulgaris. Lagenaria vulgaris is a popular vegetable, placed under the family Cucurbitaceae. This plant shows antiulcer activity through an antioxidative pathway by modulation of glutathione level [60].

6.9. Myristica malabarica. It is popularly known as rampatri, placed under the family Myristicaceae. It is used as an exotic spice in various Indian cuisines. This is credited with hepatoprotective, anticarcinogenic, and antithrombotic properties and is found as a constituent in many Ayurvedic preparations. However, most of the medicinal attributes of the spice have not been substantiated adequately. Recently, the superoxidescavenging and prolyl-endopeptidase inhibitory activities of the methanol extract of rampatrihave been reported [61]. On 
the basis of its antioxidative activity it shows NSAID induced gastric ulcer healing [62]. The active constituents of $M$. malabarica are Malabaricone B (MalB) and Malabaricone C (MalC). MalB and MalC, both two consituents, healed gastric ulceration by their antioxidative properties and modulation of EGFR expression, PGE2 synthesis and mucin secretion [63]. Mal B and C also accelerate healing of gastric ulcer by enhancing the level of VGEF, vWF factor VIII, and endostatin level [64].

6.10. Panax ginseng. The root of $P$. ginseng is a well-known Chinese drug widely used clinically for the treatment of gastrointestinal disorders as well as an erythropoietic and a tonic. Sun et al. [65] have recently compared the antiulcer activity of water soluble and alkali soluble crude polysaccharides which were separated from the roots or leaves of $P$. ginseng.

6.11. Phyllanthus emblica. Phyllanthus emblica L. or Emblica officinalis Gaertn, also known as Indian gooseberry, is a medium size deciduous tree of the Euphorbiaceae family. The fruits of P. emblica L. known as amla are consumed as fruit or in the form of food products. Ayurveda and Siddha systems of medicine have recognized the importance of this plant. It is one of the strongest rejuvenatives among Indian medicinal plants due to its anticancer $[66,67]$, anti-inflammatory [68], and antioxidative properties [69].

A clinical study has also found that amla showed a significant healing effect on gastric syndrome [70]. Our previous report presents that ethanolic extract of fruits of $P$. emblica showed antiulcer activity at a dose dependent manner mainly through its antioxidative properties by modulation of IL-10 level [71]. We have also reported that a fraction of the active component of ethanolic extract of fruits of $P$. emblica showed antiulcer activity by modulation of COX [72] or NOS pathway [73].

6.12. Picrorhiza kurroa. It is a small hairy perennial herb from Scrophulariaceae family, distributed in the alpine Himalayan tract and in some tropical parts of India. P. kurroa forms a major ingredient of many indigenous medicinal preparations and is traditionally used for dyspepsia, bilious fever, chronic dysentery, and scorpion sting. The most important active constituents of the roots and rhizomes of P. kurroa are the iridoid glycosides, picrosides I, II, III, and kutkoside, Picroside I and kutkoside has been shown to possess potent hepatoprotective [74] and gastroprotective properties mainly through their antioxidative activity [75].

6.13. Piper betle. It is a medium sized shrub, placed under the family Piperaceae. It is commonly known as pan grows widely in the tropical humid climate of South East Asia. Its leaves have a strong pungent and aromatic flavor and are widely consumed as a mouth freshener. The leaves are credited with diverse medicinal attributes in the indigenous Ayurvedic system of medicine. The $P$. betle leaf oil is known to contain primarily a class of allylbenzene compounds such as chevibetol, chavicol, hydroxychavicol (allylpyrocatechol, APC), estragole, eugenol, methyl eugenol, monoterpenes, para-cymene and terpinene, monoterpenoids, eucalyptol, and carvacrol, as well as sesquiterpenes, cadinene, and caryophyllene. However, the presence of all these compounds depends on the region where it grows; the oil has been used in respiratory troubles, cataract, and also as an antiseptic [76]. Its antiulcerogenic [77, 78] activity has been reported. One of its active components, the allylpyrocatechol, shows the best antiulcer activity mainly by modulation of arginase metabolism and shift of cytokine balance [79].

6.14. Pistacia lentiscus. Mastic is the concrete resinous exudates obtained from the tree Pistacia lentiscus (Anacardiaceae) which is activated in the Mediterranean areas. It has been used there by traditional healers for the relief of upper abdominal discomfort, gastralgia, dyspepsia, and peptic ulcer [80]. The experiment showed a significant reduction in the intensity of gastric mucosal damage induced by pyloric ligation, aspirin, phenylbutazone, reserpine, and restraint cold stress.

6.15. Pteleopsis suberosa. In clinical trials, P. suberosa showed protective action against ethanol- and indomethacin-induced gastric mucosa damage due to the stimulation of PG synthesis, the most likely active principle being a saponin fraction $[81,82]$.

6.16. Shilajit. Shilajit is the most important drug of Ayurvedic and folk-medicine systems. In the raw form it is a bituminous substance, which is a compact mass of vegetable organic matter composed of a dark red gummy matrix. It is bitter in taste and its smell resembles cow's stale urine. The botanical name of Shilajit is Asphaltum (mineral pitch). It has been used for ages in traditional medicine in the treatment of bronchial asthma, diabetes, genitourinary infections, wound healing, and stomach ulcer [83]. Antiulcer activity of 4-methoxy6-carbomethoxy biphenyl (MCB) was studied on the basis of its effect on mucin content, gastric juice carbohydrate and carbohydrate protein ratio, and on the concentration of DNA and protein in the gastric tissue. The MCB induced changes in the mucosa and provided resistance against the effect of ulcerogens and also against shedding of mucosal cells. Further studies are however required to establish their therapeutic value and rationale for use in peptic ulcer disease.

6.17. Silybum marianum. Silymarin is a flavonolignan complex present in the milk thistle, Silybum marianum, which has been found effective in some types of experimentally induced gastric ulcers. The antiulcerogenic effect of silymarin could be related to its inhibitory mechanism on the lipoxygenase pathway, avoiding leukotriene synthesis $[84,85]$.

6.18. Sophora subprostrata. Sophora subprostrata is a plant used in China for the treatment of digestive diseases [86]. Flavonoids derived from sophoradin, isolated from the root of Sophora subprostrata, are known to exhibit gastroprotective and ulcer healing properties. 
6.19. Spinacia oleracea. Spinach is an edible flowering plant in the family of Amaranthaceae. It is native to central and southwestern Asia. Spinach is a nitrate rich green vegetable. Petersson et al. observed that spinach, which gives a thicker layer of mucus lining of the gastric wall thus gives the protection from the hydrochloric acid secreted in gastric juice and reduces the risk of ulcers on rats $[87,88]$.

6.20. Tectona grandis. Parts of the common teak tree Tectona grandis have been used in formulations to treat peptic ulcer in Indian medicine. Its action appears to be associated with an effect on the protein content of gastric juice and it reversed aspirin induced changes in peptic activity, protein, and sialic acid [89].

6.21. The Unripe Plantain Banana. The medicinal properties of plantain banana are part of the tradition of folk medicine. Sanyal et al., [90, 91] for the first time, associated the plantain banana with antiulcer activity of banana against ulcer induced by phenyl butazone prednisolone and restraint stress. Later, Best et al. [92, 93] described the antiulcer activity of a variety of preparation of dried unripe plantain banana against aspirin induced ulcer in rats. They showed that only unripe plantain banana was effective both as a prophylactic treatment and also in healing the ulcers already induced by aspirin. Further studies reveal that banana increases the mucosal defence by promoting mucus secretion increasing mucoprotein content of mucosa, decreasing the shedding of cells and leakage of protein in gastric secretion in response to ulcerogenous agents, and promotes healing, as shown by the increase in thymidin uptake by gastric mucosal cells and by causing a concentration dependent increase in the eicosanoid stimulation in the incubates of human gastric and colonic mucosa $[94,95] .70 \%$ endoscopically proved duodenal ulcer healed after 12 weeks of treatment with banana powder as compared to about $16 \%$ with placebo.

6.22. Zingiber officinale. It is widely used as a condiment and therapeutic agent in many countries [96]. In Saudi Arabian traditional medicine, it is used as antiemetic, stomachic, and carminative [97]. In Chinese medicine it is employed in colic and in atonic dyspepsia and is used as a stimulant [98]. Mowrey and Clayson found that it is highly effective in motion sickness and significantly reduces gastrointestinal distress in human subjects [99]. It has also marked antiulcer activity [100].

\section{Discussion}

Amongst the various factors known to cause gastric ulcer, widespread use of nonsteroidal anti-inflammatory drugs (NSAIDs) is another major cause. NSAID is a "catch all" name for a large number of chemically distinct drugs. Functionally gastrointestinal tract is a complex organ. Drug induced functional modification of stomach could affect the normal physiology and lead to gastric lesions followed by generation of ulcer. The NSAID-induced stomach ulceration ranks fourth amongst the diseases causing morbidity and mortality.
The solution of the NSAID-induced gastropathy has so far been elusive, despite recent advances, and continues to be of concern for both clinical practitioners and researchers.

Many drugs like $\mathrm{H}_{2}$ receptor antagonists, proton pump inhibitors, and antacids are currently being used for the treatment of NSAID induced gastric ulcer. But their long term use ultimately causes significant side effects and they are expensive for the less wealthy rural population [101]. India is among the most wealthy countries for medicinal plants and plant based Ayurvedic system of medicine is the oldest system of medicine in this part of the world. A search among medicinal plants is still important in producing effective antiulcer drugs mostly devoid of these factors [102].

7.1. Phytomedicine, a Better and Alternative Therapy of Gastric Ulcer. The term "nutraceutical" was coined from "nutrition" and "pharmaceutical" in 1989 by Stephen DeFelice. According to him, nutraceutical can be defined as "a food (or part of a food) that provides medical or health benefits, including the prevention and/or treatment of a disease" [103]. In recent years, many studies have shown that diet containing high content of phytochemicals can provide protection against various diseases. Approximately $90 \%$ of diseases are avoidable by changing dietary habits only $[104,105]$. These inventions have rapidly amplified the consumer awareness of the potential benefits of naturally occurring compounds from plants in health promotion and maintenance. Hence, researches in nutraceuticals and natural health products have become the hot topics in the last few years [106-108].

Hence, a search of nutraceuticals has become essential for the development of nontoxic, inexpensive, and easily available drugs to protect different diseases including gastric ulcer.

Various pure phytochemicals have also been tested for their antiulcerogenic actions. Some of these are segregated into their chemical classes and their efficacy discussed below.

7.1.1. Flavonoids. Flavonoids are a group of about 4000 naturally occurring compounds with a wide range of biological effects, including antiulcer activity. They are important constituents of the human diet and are also found in several medicinal plants used in folk medicine around the world [109]. Several mechanisms have been proposed to explain their gastroprotective effect; these include increase of mucosal PG content [110], decrease of histamine secretion from mast cells by inhibition of histidine decarboxylase [111], and inhibition of $H$. pylori growth [112]. In addition, they are excellent free radical scavengers [113-115].

Quercetin is one of the most abundant flavonoids, found in many medicinal botanicals, including Thea sinensis, Glycyrrhiza glabra, Hypericum perforatum, Ginkgo biloba, and many others. It increases the amount of neutral glycoproteins in the gastric mucosa [109], stimulates COX [116], and inhibits the gastric proton pump [109], the lipoxygenase pathway [116], platelet activating factor synthesis [117], and lipid peroxidation [118]. Further, it scavenges various free radicals effectively while enhancing glutathione peroxidase 
activity significantly [119]. Interestingly, it also inhibits the growth of $H$. pylori in vitro [112].

Naringin, a flavonoid glycoside has been shown to prevent chronic gastric ulceration caused by restraint stress, pyloric occlusion, and ethanol [120-123]. Its gastroprotective action is mediated through a complex PG-independent mechanism that involves an increase in the glycoprotein content and viscosity of the gastric mucosa. Its antioxidant property might also [124-126] contribute to its gastroprotective effect.

In India, like other parts of the world, market available medicines are widely used for the prevention of different diseases, like inflammation, hypertension, pain sensation, gastritis, cancer, and so forth. But long term use of such synthetic medicines ultimately causes gastroduodenal risks. So, there is a growing need to find naturally synthesized plant based medicines which are devoid of this side effect.

The healing potential of the plants is due to their ability to synthesize the aromatic substances such as phenols and flavonoids, which serves as defense mechanism against different diseases. These substances scavenge the free radicals generated on administration of NSAIDs and increase the cellular defense activity.

The nonsteroidal anti-inflammatory drugs exert both their therapeutic and toxic effects mainly through the control of the activity of cyclooxygenase. But long term use of such painkillers inhibits the cyclooxygenases (COX) activity and decreases the levels of circulating prostaglandin (PG) at the gastric mucosa causing gastric ulceration and also exacerbating preexisting gastric ulcers in rodents and humans $[28,127]$.

The antiulcerogenic potential of the natural polyphenols (drugs) could be attributed to their divergent effects on angiogenesis. Gastric ulcer healing is a complex process involving angiogenesis and cell proliferation. All these eventually help in wound retraction and reepithelization by regulation of proangiogenic factors as well as antiangiogenic factors. Clinical and other experimental data consider the role of angiogenesis during NSAID induced gastropathy; the effect of the plant drugs may augment the growth of new blood vessels and decrease their ulcer healing action.

So, addition of neutraceuticals in daily habit is the alternate therapy to protect from different diseases by preventing oxidative stress and improving the stores of critical elements such as antioxidants, vitamins, and so forth.

\section{Conflict of Interests}

The authors declare that there is no conflict of interests regarding the publication of this paper.

\section{References}

[1] H. Zaman, "The Southeast Asia region," in Traditional Medicine, R. H. Bannerman, Ed., pp. 231-239, World Health Organization, Geneva, Switzerland, 1974.

[2] N. Nakatani, "Phenolic antioxidants from herbs and spices," BioFactors, vol. 13, no. 1-4, pp. 141-146, 2000.
[3] J. Kanner and T. Lapidot, "The stomach as a bioreactor: dietary lipid peroxidation in the gastric fluid and the effects of plantderived antioxidants," Free Radical Biology and Medicine, vol. 31, no. 11, pp. 1388-1395, 2001.

[4] I. Gurbuz, C. Akyuz, E. Yesilada, and B. Sener, "Anti-ulcerogenic effect of Momordica charantia L. fruits on various ulcer models in rats," Journal of Ethnopharmacology, vol. 71, no. 1-2, pp. 77-82, 2000.

[5] S. Mahadeva and K.-L. Goh, "Epidemiology of functional dyspepsia: a global perspective," World Journal of Gastroenterology, vol. 12, no. 17, pp. 2661-2666, 2006.

[6] Z. Ge and D. E. Taylor, "Contributions of genome sequencing to understanding the biology of Helicobacter pylori," Annual Review of Microbiology, vol. 53, pp. 353-387, 1999.

[7] D. R. Cave, "Transmission and epidemiology of Helicobactor pylori," The American Journal of Medicine, vol. 100, no. 1, pp. 12 17, 1996.

[8] A. Chatterjee, S. Chatterjee, and S. K. Bandyopadhyay, " $H$. pylori-induced gastric ulcer: pathophysiology and herbal remedy," International Journal of Biological \& Medical Research, vol. 3, no. 1, pp. 1461-1465, 2012.

[9] A. S. Tarnawski and M. K. Jones, "Inhibition of angiogenesis by NSAIDs: molecular mechanisms and clinical implications," Journal of Molecular Medicine, vol. 81, no. 10, pp. 627-636, 2003.

[10] P. Brooks, P. Emery, J. F. Evans et al., "Interpreting the clinical significance of the differential inhibition of COX-1 and COX-2," Rheumatology, vol. 38, no. 8, pp. 779-788, 1999.

[11] A. Lanas, M. A. Perez-Aisa, F. Feu et al., "A nationwide study of mortality associated with hospital admission due to severe gastrointestinal events and those associated with nonsteroidal antiinflammatory drug use," American Journal of Gastroenterology, vol. 100, no. 8, pp. 1685-1693, 2005.

[12] D. E. Moerman, "An analysis of the food plants and drug plants of native North America," Journal of Ethnopharmacology, vol. 52, no. 1, pp. 1-22, 1996.

[13] A. Hossenbocus and D. G. Colin-Jones, "Proceedings: the effects of aspirin, carbenoxolone, and gefarnate on the gastric mucosal potential difference in man," Gut, vol. 15, no. 4, pp. 335336, 1974.

[14] Y. Katoh, M. Tanaka, and H. Kawashima, "Protective effects of teprenone and gefarnate against taurocholate/hydrochloric acid-induced acute gastric mucosal lesions in rats," Nippon Yakurigaku Zasshi, vol. 112, no. 5, pp. 323-331, 1998.

[15] D. G. Payan and B. G. Katzung, "Non-steroidal anti-inflammatory drugs; nonopoid analgesics; drugs used in gout," Basic and Clinical Pharmacology, vol. 6, pp. 536-559, 1995.

[16] L. Brunton, B. Chabner, and B. Knollman, "Anti-inflammatory, antipyretic, and analgesic agents: pharmacotherapy of gout," in The Pharmacological Basis of Therapeutics, W. H. Freeman, Ed., Goodman and Gilman's, pp. 959-1004, Mcgraw-Hill, New York, NY, USA, 12th edition, 2011.

[17] T. Yoshikawa, Y. Naito, A. Kishi et al., "Role of active oxygen, lipid peroxidation, and antioxidants in the pathogenesis of gastric mucosal injury induced by indomethacin in rats," Gut, vol. 34, no. 6, pp. 732-737, 1993.

[18] C. J. Hawkey and D. S. Rampton, "Prostaglandins and the gastrointestinal mucosa: are they important in its function, disease, or treatment?" Gastroenterology, vol. 89, no. 5, pp. 1162$1188,1985$.

[19] K. Wong and K. Freund, "Inhibition of the n-formylmethionylleucyl-phenylalanine induced respiratory burst in human neutrophils by adrenergic agonists and prostaglandins of the $\mathrm{E}$ 
series," Canadian Journal of Physiology and Pharmacology, vol. 59, no. 9, pp. 915-920, 1981.

[20] M. K. Jones, H. Wang, B. M. Peskar et al., "Inhibition of angiogenesis by nonsteroidal anti-inflammatory drugs: insight into mechanisms and implications for cancer growth and ulcer healing," Nature Medicine, vol. 5, no. 12, pp. 1418-1423, 1999.

[21] J. L. Wallace, "Recent advances in gastric ulcer therapeutics," Current Opinion in Pharmacology, vol. 5, no. 6, pp. 573-577, 2005.

[22] M. N. Muscara and J. L. Wallace, "Nitric oxide. V. therapeutic potential of nitric oxide donors and inhibitors," American Journal of Physiology: Gastrointestinal and Liver Physiology, vol. 276, no. 6, part 1, pp. G1313-G1316, 1999.

[23] J. L. Wallace, C. M. Keenan, and D. N. Granger, "Gastric ulceration induced by nonsteroidal anti-inflammatory drugs is a neutrophil-dependent process," American Journal of Physiology: Gastrointestinal and Liver Physiology, vol. 259, no. 3, part 1, pp. G462-G467, 1990.

[24] J. Piotrowski, A. Slomiany, and B. L. Slomiany, "Activation of apoptotic caspase-3 and nitric oxide synthase-2 in gastric mucosal injury induced by indomethacin," Scandinavian Journal of Gastroenterology, vol. 34, no. 2, pp. 129-134, 1999.

[25] J. L. Wallace and M. J. Miller, "Nitric oxide in mucosal defense: a little goes a long way," Gastroenterology, vol. 119, no. 2, pp. 512$520,2000$.

[26] C. J. Hawkey, "Non-steroidal anti-inflammatory drugs and peptic ulcers. Facts and figures multiply, but do they add up?" British Medical Journal, vol. 300, no. 6720, pp. 278-284, 1990.

[27] M. J. Lancaster-Smith, M. R. Jaderberg, and D. A. Jackson, "Ranitidine in the treatment of non-steroidal antiinflammatory drug associated gastric and duodenal ulcers," Gut, vol. 32, no. 3, pp. 252-256, 1991.

[28] F. Halter, A. S. Tarnawski, A. Schmassmann, and B. M. Peskar, "Cyclooxygenase 2-implications on maintenance of gastric mucosal integrity and ulcer healing: controversial issues and perspectives," Gut, vol. 49, no. 3, pp. 443-453, 2001.

[29] D. Baatar, M. K. Jones, R. Pai et al., "Selective COX-2 blocker delays healing of experimental esophageal ulcers and inhibits ulceration-triggered c-Met/HGF receptor induction and ERK2 activation," The American Journal of Gastroenterology, vol. 97, pp. 542-553, 2002.

[30] L. Ma, P. D. Soldato, and J. L. Wallace, "Divergent effects of new cyclooxygenase inhibitors on gastric ulcer healing: shifting the angiogenic balance," Proceedings of the National Academy of Sciences of the United States of America, vol. 99, no. 20, pp. 13243-13247, 2002.

[31] M. K. Jones, H. Wang, B. M. Peskar et al., "Inhibition of angiogenesis by nonsteroidal anti-inflammatory drugs: insight into mechanisms and implications for cancer growth and ulcer healing," Nature Medicine, vol. 5, no. 12, pp. 1418-1423, 1999.

[32] T. Pawlik, P. C. Konturek, J. W. Konturek et al., "Impact of Helicobacter pylori and nonsteroidal anti-inflammatory drugs on gastric ulcerogenesis in experimental animals and in humans," European Journal of Pharmacology, vol. 449, no. 1-2, pp. 1-15, 2002.

[33] T. Brzozowski, P. C. Konturek, Z. Liwowski et al., "Interaction of nonsteroidal anti-inflammatory drugs (NSAID) with Helicobacter pylori in the stomach of humans and experimental animals," Journal of Physiology and Pharmacology, vol. 57, no. 3, pp. 67-79, 2006.

[34] M. Karthikeyan and K. Deepa, "Therapeutic applications of nitric oxide releasing non steroidal anti-inflammatory drugs,"
Journal of Chemical and Pharmaceutical Research, vol. 1, no. 1, pp. 134-147, 2009.

[35] K. Takeuchi, H. Ukawa, A. Konaka, M. Kitamura, and Y. Sugawa, "Effect of nitric oxide-releasing aspirin derivative on gastric functional and ulcerogenic responses in rats: comparison with plain aspirin," Journal of Pharmacology and Experimental Therapeutics, vol. 286, no. 1, pp. 115-121, 1998.

[36] S. Fiorucci and L. Santucci, "Hydrogen sulfide-based therapies: focus on $\mathrm{H}_{2} \mathrm{~S}$ releasing NSAIDs," Inflammation \& Allergy Drug Targets, vol. 10, no. 2, pp. 133-140, 2011.

[37] L. Zhi, A. D. Ang, H. Zhang, P. K. Moore, and M. Bhatia, "Hydrogen sulfide induces the synthesis of proinflammatory cytokines in human monocyte cell line U937 via the ERK-NF$\kappa \mathrm{B}$ pathway," Journal of Leukocyte Biology, vol. 81, no. 5, pp. 1322-1332, 2007.

[38] G. Caliendo, G. Cirino, V. Santagada, and J. L. Wallace, "Synthesis and biological effects of hydrogen sulfide $\left(\mathrm{H}_{2} \mathrm{~S}\right)$ : development of $\mathrm{H}_{2} \mathrm{~S}$-releasing drugs as pharmaceuticals," Journal of Medicinal Chemistry, vol. 53, no. 17, pp. 6275-6286, 2010.

[39] A. Cristoni and M. J. Magistretti, "Antiulcer and healing activity of Vaccinium myrtillus anthocyandosides," Il Farmaco, vol. 42, no. 2, pp. 29-43, 1987.

[40] M. J. Magistretti, M. Conti, and A. Cristoni, "Antiulcer activity of an anthocyanidin from Vaccinium myrtillus," Arzneimittel Forschung, vol. 38, no. 5, pp. 686-690, 1988.

[41] T. Al-Howiriny, A. Alsheikh, S. Alqasoumi, M. Al-Yahya, K. Eltahir, and S. Rafatullah, "Gastric antiulcer, antisecretory and cytoprotective properties of celery (Apium graveolens) in rats," Pharmaceutical Biology, vol. 48, no. 7, pp. 786-793, 2010.

[42] M. Shibata, R. Yoshida, S. Motohashi, and M. Fukushima, "Pharmacologic studies on Bupleurum falcatum L. IV. Some pharmacologic effects of crude saikosides, saikogenin A and syrupy residue," Yakugaku Zasshi, vol. 93, no. 12, pp. 1660-1667, 1973.

[43] H. Yamada, K.-S. Ra, H. Kiyohara, J.-C. Cyong, and Y. Otsuka, "Structural characterisation of an anti-complementary pectic polysaccharide from the roots of Bupleurum falcatum L," Carbohydrate Research, vol. 189, pp. 209-226, 1989.

[44] S. Swarnakar, K. Ganguly, P. Kundu, A. Banerjee, P. Maity, and A. V. Sharma, "Curcumin regulates expression and activity of matrix metalloproteinases 9 and 2 during prevention and healing of indomethacin-induced gastric ulcer," The Journal of Biological Chemistry, vol. 280, no. 10, pp. 9409-9415, 2005.

[45] M.-T. Huang, T. Lysz, T. Ferraro, T. F. Abidi, J. D. Laskin, and A. $\mathrm{H}$. Conney, "Inhibitory effects of curcumin on in vitro lipoxygenase and cyclooxygenase activities in mouse epidermis," Cancer Research, vol. 51, no. 3, pp. 813-819, 1991.

[46] C. Niederau and E. Gopfert, "The effect of chelidonium- and turmeric root extract on upper abdominal pain due to functional disorders of the biliary system. Results from a placebocontrolled double-blind study," Medizinische Klinik, vol. 94, no. 8, pp. 425-430, 1999.

[47] C. Prucksunand, B. Indrasukhsri, M. Leethochawalit, and K. Hungspreugs, "Phase II clinical trial on effect of the long turmeric (Curcuma longa Linn) on healing of peptic ulcer," Southeast Asian Journal of Tropical Medicine and Public Health, vol. 32, no. 1, pp. 208-215, 2001.

[48] F. Zhang, N. K. Altorki, J. R. Mestre, K. Subbaramaiah, and A. J. Dannenberg, "Curcumin inhibits cyclooxygenase-2 transcription in bile acid- and phorbol ester-treated human gastrointestinal epithelial cells," Carcinogenesis, vol. 20, no. 3, pp. 445-451, 1999. 
[49] M. Yoshikawa, T. Morikawa, N. Li, A. Nagatomo, X. Li, and H. Matsuda, "Bioactive saponins and glycosides. XXIII. Triterpene saponins with gastroprotective effect from the seeds of Camellia sinensis-theasaponins E3, E4, E5, E6, and E7," Chemical \& Pharmaceutical Bulletin, vol. 53, no. 12, pp. 1559-1564, 2005.

[50] T. Morikawa, N. Li, A. Nagatomo, H. Matsuda, X. Li, and M. Yoshikawa, "Triterpene saponins with gastroprotective effects from tea seed (the seeds of Camellia sinensis)," Journal of Natural Products, vol. 69, no. 2, pp. 185-190, 2006.

[51] S. Maity, J. R. Vedasiromoni, L. Chaudhuri, and D. K. Ganguly, "Role of reduced glutathione and nitric oxide in the black tea extract-mediated protection against ulcerogen-induced changes in motility and gastric emptying in rats," Japanese Journal of Pharmacology, vol. 85, no. 4, pp. 358-364, 2001.

[52] S. Maity, J. R. Vedasiromoni, and D. K. Ganguly, "Anti-ulcer effect of the hot water extract of black tea (Camellia sinensis)," Journal of Ethnopharmacology, vol. 46, no. 3, pp. 167-174, 1995.

[53] B. Adhikary, S. K. Yadav, K. Roy, S. K. Bandyopadhyay, and S. Chattopadhyay, "Black tea and theaflavins assist healing of indomethacin-induced gastric ulceration in mice by antioxidative action," Evidence-Based Complementary and Alternative Medicine, vol. 2011, Article ID 546560, 11 pages, 2011.

[54] J. A. Duke, Handbook of Medicinal Herbs, CRC Press, Boca Raton, Fla, USA, 1985.

[55] A. G. Turpie, J. Runcie, and T. J. Thomson, "Clinical trial of deglydyrrhizinized liquorice in gastric ulcer," Gut, vol. 10, no. 4, pp. 299-302, 1969.

[56] P. A. Bafna and R. Balaraman, "Anti-ulcer and anti-oxidant activity of Pepticare, a herbomineral formulation," Phytomedicine, vol. 12, no. 4, pp. 264-270, 2005.

[57] A. R. Dehpour, M. E. Zolfaghari, T. Samadian, and Y. Vahedi, "The protective effect of liquorice components and their derivatives against gastric ulcer induced by aspirin in rats," Journal of Pharmacy and Pharmacology, vol. 46, no. 2, pp. 148-149, 1994.

[58] H. Matsuda, Y. Li, T. Murakami, J. Yamahara, and M. Yoshikawa, "Protective effects of oleanolic acid oligoglycosides on ethanolor indomethacin-induced gastric mucosal lesions in rats," Life Sciences, vol. 63, no. 17, pp. PL245-PL250, 1998.

[59] H. Saito, Y. M. Lee, K. Takagi, S. Shoji, and N. Kondo, "Pharmacological studies of Panacis japonici rhizoma," Chemical and Pharmaceutical Bulletin, vol. 25, no. 5, pp. 1017-1025, 1977.

[60] V. B. Mehta, V. J. Sharma, M. F. Shaikh, P. D. Amin, and S. Sathaye, "Evaluation of antioxidant and immunomodulatory activity of Lagenaria vulgaris," International Journal of Research in Pharmaceutical Sciences, vol. 2, no. 3, pp. 393-398, 2011.

[61] F. Khanom, H. Kayahara, and K. Tadasa, "Superoxidescavenging and prolyl endopeptidase inhibitory activities of Bangladeshi indigenous medicinal plants," Bioscience, Biotechnology and Biochemistry, vol. 64, no. 4, pp. 837-840, 2000.

[62] D. Banerjee, A. K. Bauri, R. K. Guha, S. K. Bandyopadhyay, and S. Chattopadhyay, "Healing properties of malabaricone $\mathrm{B}$ and malabaricone $\mathrm{C}$, against indomethacin-induced gastric ulceration and mechanism of action," European Journal of Pharmacology, vol. 578, no. 2-3, pp. 300-312, 2008.

[63] D. Banerjee, B. Maity, A. K. Bauri, S. K. Bandyopadhyay, and S. Chattopadhyay, "Gastroprotective properties of Myristica malabarica against indometacin-induced stomach ulceration: a mechanistic exploration," Journal of Pharmacy and Pharmacology, vol. 59, no. 11, pp. 1555-1565, 2007.
[64] B. Maity and S. Chattopadhyay, "Natural antiulcerogenic agents: an overview," Current Bioactive Compounds, vol. 4, no. 4, pp. 225-244, 2008.

[65] X.-B. Sun, T. Matsumoto, and H. Yamada, "Purification of an anti-ulcer polysaccharide from the leaves of Panax ginseng," Planta Medica, vol. 58, no. 5, pp. 445-448, 1992.

[66] M. T. Khan, I. Lampronti, D. Martello et al., "Identification of pyrogallol as an antiproliferative compound present in extracts from the medicinal plant Emblica officinalis: effects on in vitro cell growth of human tumor cell lines," International journal of oncology, vol. 21, no. 1, pp. 187-192, 2002.

[67] E. Lambertini, R. Piva, M. T. Khan et al., "Effects of extracts from Bangladeshi medicinal plants on in vitro proliferation of human breast cancer cell lines and expression of estrogen receptor alpha gene," International Journal of Oncology, vol. 24, no. 2, pp. 419-423, 2004.

[68] A. Ihantola-Vormisto, J. Summanen, H. Kankaanranta, H. Vuorela, Z. M. Asmawi, and E. Moilanen, "Anti-inflammatory activity of extracts from leaves of Phyllanthus emblica," Planta Medica, vol. 63, no. 6, pp. 518-524, 1997.

[69] S. K. Bandyopadhyay, S. C. Pakrashi, and A. Pakrashi, "The role of antioxidant activity of Phyllanthus emblica fruits on prevention from indomethacin induced gastric ulcer," Journal of Ethnopharmacology, vol. 70, no. 2, pp. 171-176, 2000.

[70] Singh and Sharma, "Acid balancing effect on digestive system: clinical studies were conducted to investigate the effect of amalaki in amlapitta (Gastritis syndrome)," Indian Journal of Medical Research, vol. 34, pp. 98-99, 1971.

[71] A. Chatterjee, S. Chattopadhyay, and S. K. Bandyopadhyay, "Biphasic effect of Phyllanthus emblica L. extract on NSAIDinduced ulcer: an antioxidative trail weaved with immunomodulatory effect," Evidence-Based Complementary and Alternative Medicine, vol. 2011, Article ID 146808, 13 pages, 2011.

[72] A. Chatterjee, S. Chatterjee, S. Das, A. Saha, S. Chattopadhyay, and S. K. Bandyopadhyay, "Ellagic acid facilitates indomethacin-induced gastric ulcer healing via COX-2 upregulation," Acta Biochimica et Biophysica Sinica, vol. 44, no. 7, pp. 565-576, 2012.

[73] A. Chatterjee, S. Chatterjee, A. Biswas, S. Bhattecharya, S. Chattopadhyay, and S. K. Bandyopadhyay, "Gallic acid enriched fraction of Phyllanthus emblica potentiates indomethacininduced gastric ulcer healing via e-NOS-dependent pathway," Evidence-Based Complementary and Alternative Medicine, vol. 2012, Article ID 487380, 13 pages, 2012.

[74] Y. Dwivedi, R. Rastogi, N. K. Garg, and B. N. Dhawan, "Picroliv and its components kutkoside and picroside I protect liver against galactosamine-induced damage in rats," Pharmacology \& Toxicology, vol. 71, no. 5, pp. 383-387, 1992.

[75] D. Banerjee, S. Bhattacharya, S. K. Bandyopadhyay, and S. Chattopadhyay, "Picrorhiza kurroa-phytochemical and pharmacological evaluation," in Recent Progress in Medicinal Plants, J. N. Govil, Ed., vol. 24, pp. 69-89, Stadium Press, Houston, Tex, USA, 2009.

[76] H. Panda, Herbs Cultivation and Medicinal Uses, National Institute of Industrial Re, Delhi, India, 2004.

[77] S. Bhattacharya, D. Banerjee, A. K. Bauri, S. Chattopadhyay, and S. K. Bandyopadhyay, "Healing property of the Piper betel phenol, allylpyrocatechol against indomethacin-induced stomach ulceration and mechanism of action," World Journal of Gastroenterology, vol. 13, no. 27, pp. 3705-3713, 2007.

[78] B. Majumdar, S. R. Chaudhuri, A. Ray, and S. K. Bandyopadhyay, "Potent antiulcerogenic activity of ethanol extract of leaf 
of Piper betle linn by antioxidative mechanism," Indian Journal of Clinical Biochemistry, vol. 17, no. 1, pp. 49-57, 2002.

[79] S. K. Yadav, B. Adhikary, B. Maity, S. K. Bandyopadhyay, and S. Chattopadhyay, "The gastric ulcer-healing action of allylpyrocatechol is mediated by modulation of arginase metabolism and shift of cytokine balance," European Journal of Pharmacology, vol. 614, no. 1-3, pp. 106-113, 2009.

[80] M. Al-Said, A. Ageel, N. S. Parmar, and M. Tariq, "Evaluation of mastic, a crude drug obtained from Pistacia lentiscus for gastric and duodenal anti-ulcer activity," Journal of Ethnopharmacology, vol. 15, no. 3, pp. 271-278, 1986.

[81] R. de Pasquale, M. P. Germano, A. Keita, R. Sanogo, and L. Iauk, "Antiulcer activity of Pteleopsis suberosa," Journal of Ethnopharmacology, vol. 47, no. 1, pp. 55-58, 1995.

[82] M. P. Germanò, R. Sanogo, M. Guglielmo, R. de Pasquale, G. Crisafi, and G. Bisignano, "Effects of Pteleopsis suberosa extracts on experimental gastric ulcers and Helicobacter pylori growth," Journal of Ethnopharmacology, vol. 59, no. 3, pp. 167-172, 1998.

[83] R. K. Goel, R. S. Banerjee, and S. B. Acharya, "Antiulcerogenic and antiinflammatory studies with shilajit," Journal of Ethnopharmacology, vol. 29, no. 1, pp. 95-103, 1990.

[84] A. Bindoli, S. Cavallini, and N. Siliprandi, "Accion inhibidora de la silimarina sobre la peroxidacion lipidica en los microsomas y mitocondrias hepaticos de la rata," Biochemical Pharmacology, vol. 26, pp. 2405-2409, 1977.

[85] C. Alarcon de la Lastra, M. J. Martin, and E. Marhuenda, "Gastric anti-ulcer activity of silymarin, a lipoxygenase inhibitor, in rats," Journal of Pharmacy and Pharmacology, vol. 44, no. 11, pp. 929-931, 1992.

[86] K. Kyogoku, K. Hatayama, S. Yokomori et al., "Anti-ulcer effect of isoprenyl flavonoids. Synthesis and anti-ulcer activity of new chalone related to sophoradain," Chemical \& Pharmaceutical Bulletin, vol. 27, no. 12, pp. 2943-2948, 1979.

[87] J. Petersson, M. Phillipson, E. A. Jansson, A. Patzak, J. O. Lundberg, and L. Holm, "Dietary nitrate increases gastric mucosal blood flow and mucosal defense," American Journal of Physiology: Gastrointestinal and Liver Physiology, vol. 292, no. 3, pp. G718-G724, 2007.

[88] H. Bjorne, J. Petersson, M. Phillipson, E. Weitzberg, L. Holm, and J. O. Lundberg, "Nitrite in saliva increases gastric mucosal blood flow and mucus thickness," The Journal of Clinical Investigation, vol. 113, no. 1, pp. 106-114, 2004.

[89] R. K. Goel, N. K. R. Pathak, and M. Biswas, "Effect of lapachol, a naphthaquinone isolated from Tectona grandis, on experimental peptic ulcer and gastric secretion," Journal of Pharmacy and Pharmacology, vol. 39, no. 2, pp. 138-140, 1987.

[90] R. K. Sanyal, P. K. Das, S. Sinha, and Y. K. Sinha, "Banana and gastric secretion," Journal of Pharmacy and Pharmacology, vol. 13, no. 1, pp. 318-319, 1961.

[91] A. K. Sanyal, K. K. Gupta, and N. K. Chowdhury, "Banana and experimental peptic ulcer," Journal of Pharmacy and Pharmacology, vol. 15, no. 1, pp. 283-284, 1963.

[92] R. Best, D. A. Lewis, and N. Nasser, "The anti-ulcerogenic activity of the unripe plantain banana (Musa species)," British Journal of Pharmacology, vol. 82, no. 1, pp. 107-116, 1984.

[93] R. C. Elliott and G. J. F. Heward, "The influence of a banana supplemented diet on gastric ulcers in mice," Pharmacological Research Communications, vol. 8, no. 2, pp. 167-171, 1976.

[94] R. K. Goel, S. Gupta, R. K. Shankar, and A. K. Sanyal, "Antiulcerogenic effect of banana powder (Musa sapientum varpara paradisiaca) and its effect on mucosal resistance," Journal of Ethnopharmacology, vol. 18, no. 1, pp. 33-44, 1986.
[95] R. K. Goel, I. A. Tavares, and A. Bennett, "Stimulation of gastric and colonic mucosal eicosanoid synthesis by plantain banana," Journal of Pharmacy and Pharmacology, vol. 41, no. 11, pp. 747750, 1989.

[96] M. Stuart, The Encyclopedia of Herbs and Herbalism, Orbis, London, UK, 1979.

[97] A. M. Ageel, J. S. Mossa, M. Tariq, M. A. Al-Yahya, and M. S. AlSaid, Plants Used in Saudi Folk Medicine, King Saud University Press, Riyadh, Saudi Arabia, 1987.

[98] J. D. Keys, Chinese Herbs, Tuttle Company, Tokyo, Japan, 3rd edition, 1985.

[99] D. B. Mowrey and D. E. Clayson, "Motion sickness, ginger, and psychophysics," The Lancet, vol. 1, no. 8273, pp. 655-657, 1982.

[100] M. A. Al-Yahya, S. Rafatullah, J. S. Mossa, A. M. Ageel, N. S. Parmar, and M. Tariq, "Gastroprotective activity of ginger Zingiber officinale rose, in albino rats," American Journal of Chinese Medicine, vol. 17, no. 1-2, pp. 51-56, 1989.

[101] W. Toma, J. R. Trigo, A. C. B. Paula, and A. R. M. S. Brito, "Preventive activity of pyrrolizidine alkaloids from Senecio brasiliensis (Asteraceae) on gastric and duodenal induced ulcer on mice and rats," Journal of Ethnopharmacology, vol. 95, no. 23, pp. 345-351, 2004.

[102] F. Borrelli and A. A. Izzo, "The plant kingdom as a source of anti-ulcer remedies," Phytotherapy Ressearch, vol. 14, no. 8, pp. 581-591, 2000.

[103] P. Toniolo, A. L. van Kappel, A. Akhmedkhanov et al., "Serum carotenoids and breast cancer," American Journal of Epidemiology, vol. 153, no. 12, pp. 1142-1147, 2001.

[104] C. A. Swanson, "Vegetables, fruits, and cander risk: the role of phytochemicals," in Phytochemicals: A New Paradigm, W. R. Bidlack, S. T. Omaye, M. S. Meskin, and D. Johner, Eds., pp. 1-12, Technomic, Lancaster, Pa, USA, 1998.

[105] V. Brower, "Nutraceuticals: poised for a healthy slice of the healthcare market?" Nature Biotechnology, vol. 16, no. 8, pp. 728-731, 1998.

[106] G. Block, B. Patterson, and A. Subar, "Fruit, vegetables, and cancer prevention: a review of the epidemiological evidence," Nutrition and Cancer, vol. 18, no. 1, pp. 1-29, 1992.

[107] D. Trichopoulos and W. C. Willett, "Introduction: nutrition and cancer," Cancer Causes \& Control, vol. 7, no. 1, pp. 3-4, 1996.

[108] K. A. Steinmetz and J. D. Potter, "Vegetables, fruit, and cancer. II. Mechanisms," Cancer Causes \& Control, vol. 2, no. 6, pp. 427442, 1991.

[109] G. di Carlo, N. Mascolo, A. A. Izzo, and F. Capasso, "Flavonoids: old and new aspects of a class of natural therapeutic drugs," Life Sciences, vol. 65, no. 4, pp. 337-353, 1999.

[110] M. J. Alcaraz and J. R. Hoult, "Actions of flavonoids and the novel anti-inflammatory flavone, hypolaetin-8-glucoside, on prostaglandin biosynthesis and inactivation," Biochemical Pharmacology, vol. 34, no. 14, pp. 2477-2482, 1985.

[111] C. Bronner and Y. Landry, "Kinetics of the inhibitory effect of flavonoids on histamine secretion from mast cells," Agents and Actions, vol. 16, no. 3-4, pp. 147-151, 1985.

[112] W. Beil, C. Birkholz, and K.-F. Sewing, "Effects of flavonoids on parietal cell acid secretion, gastric mucosal prostaglandin production and Helicobacter pylori growth," Arzneimittel Forschung, vol. 45, no. 6, pp. 697-700, 1995.

[113] J. Baumann, G. Wurm, and F. Bruchhausen, "Prostaglandin synthetase inhibition by flavonoids and phenolic compounds in relation to their oxygen-scavenging properties," Archiv der Pharmazie, vol. 313, no. 4, pp. 330-337, 1980. 
[114] L. Cavallini, A. Bindoli, and N. Siliprandi, "Comparative evaluation of antiperoxidative action of silymarin and other flavonoids," Pharmacological Research Communications, vol. 10, no. 2, pp. 133-136, 1978.

[115] R. Salvayre, P. Braquet, L. Perruchot, and L. Douste-Blazy, "Comparison of the scavenger effect of bilberry anthocyanosides with various favonoids," Flavonoids Bioflavonoids, vol. 11, pp. 437-442, 1982.

[116] M.-A. Moroney, M. J. Alcaraz, R. A. Forder, F. Carey, and S. R. S. Hoult, "Selectivity of neutrophil 5-lipoxygenase and cyclo-oxygenase inhibition by an anti-inflammatory flavonoid glycoside and related aglycone flavonoids," Journal of Pharmacy and Pharmacology, vol. 40, no. 11, pp. 787-792, 1988.

[117] A. A. Izzo, G. di Carlo, N. Mascolo, G. Autore, and F. Capasso, "Antiulcer effect of flavonoids. Role of endogenous PAF," Phytotherapy Research, vol. 8, no. 3, pp. 179-181, 1994.

[118] C. Alarcon de la Lastra, M. J. Martin, and V. Motilva, "Antiulcer and gastroprotective effects of quercetin: a gross and histologic study," Pharmacology, vol. 48, no. 1, pp. 56-62, 1994.

[119] M. J. Martin, C. la Casa, C. Alarcon de la Lastra, J. Cabeza, I. Villegas, and V. Motilva, "Anti-oxidant mechanisms involved in gastroprotective effects of quercetin," Zeitschrift für Naturforschung, vol. 53, no. 1-2, pp. 82-88, 1998.

[120] N. S. Parmar, "The gastric anti-ulcer activity of naringenin, a specific histidine decarboxylase inhibitor," International Journal of Tissue Reactions, vol. 5, no. 4, pp. 415-420, 1983.

[121] M. J. Martin, V. Motilva, and C. Alarcon de la Lastra, "Quercetin and naringenin: effects on ulcer formation and gastric secretion in rats," Phytotherapy Research, vol. 7, no. 2, pp. 150-153, 1993.

[122] V. Motilva, C. Alarcon de la Lastra, M. J. Martin, and J. Torreblanca, "Effects of naringenin and quercetin on experimental chronic gastric ulcer in rat. Studies on the histological findings," Phytotherapy Research, vol. 6, no. 3, pp. 168-170, 1992.

[123] V. Motilva, C. Alarcon de la Lastra, and M. J. Martin, "Ulcerprotecting effects of naringenin on gastric lesions induced by ethanol in rat: role of endogenous prostaglandins," Journal of Pharmacy and Pharmacology, vol. 46, no. 2, pp. 91-94, 1994.

[124] J. Robak and R. Gryglewski, "Flavonoids are scavengers of superoxide anions," Biochemical Pharmacology, vol. 37, no. 5, pp. 837-841, 1988.

[125] J. Robak, F. Shridi, M. Wolbis, and M. Kerolikowska, "Screening of the influence of flavonoids on lipoxygenase and cyclooxygenase activity, as well as on nonenzymic lipid oxidation," Polish Journal of Pharmacology and Pharmacy, vol. 40, no. 5, pp. 451458, 1988.

[126] M. J. Martin, E. Marhuenda, C. Perez-Guerrero, and J. M. Franco, "Antiulcer effect of naringin on gastric lesions induced by ethanol in rats," Pharmacology, vol. 49, no. 3, pp. 144-150, 1994.

[127] J. L. Wallace, "Nonsteroidal anti-inflammatory drugs and gastroenteropathy: the second hundred years," Gastroenterology, vol. 112, no. 3, pp. 1000-1016, 1997. 


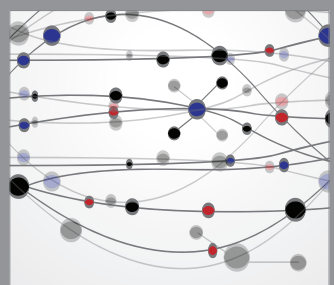

The Scientific World Journal
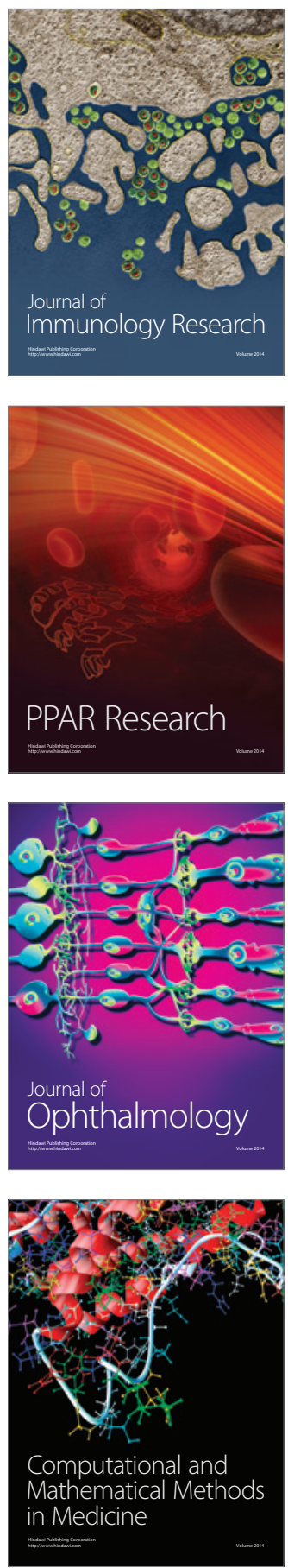

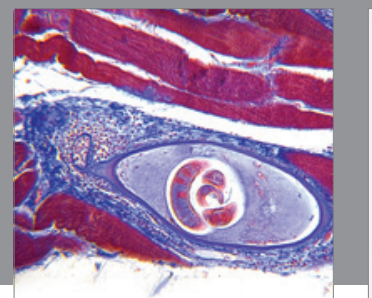

Gastroenterology

Research and Practice
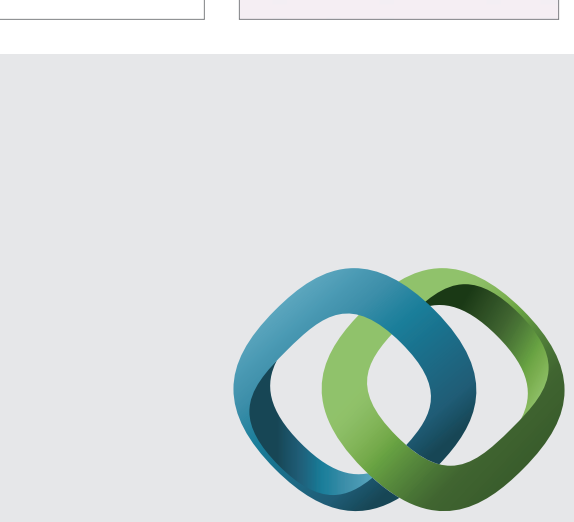

\section{Hindawi}

Submit your manuscripts at

http://www.hindawi.com
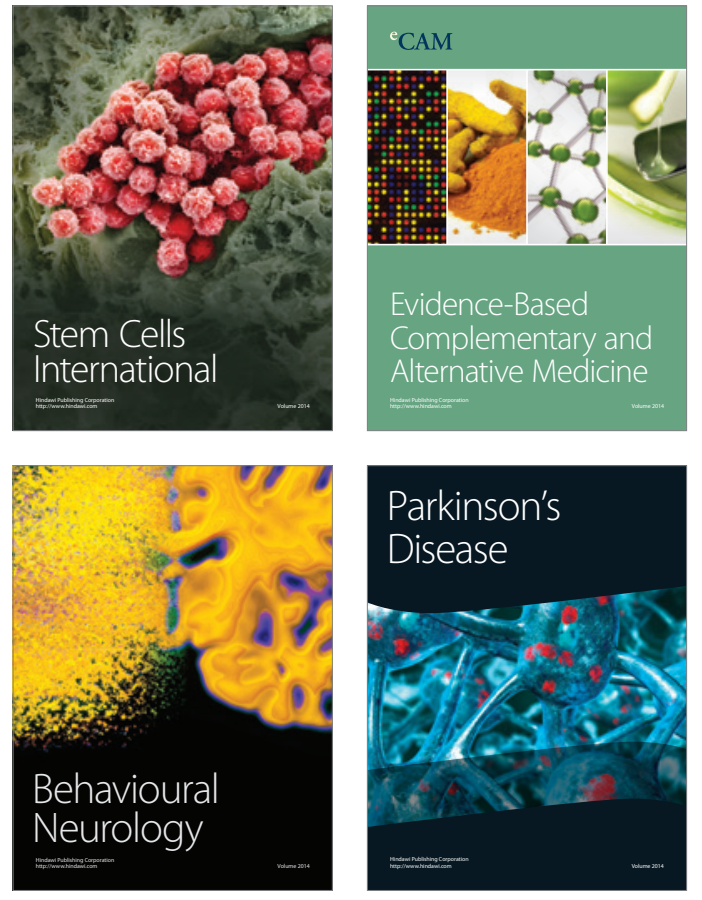
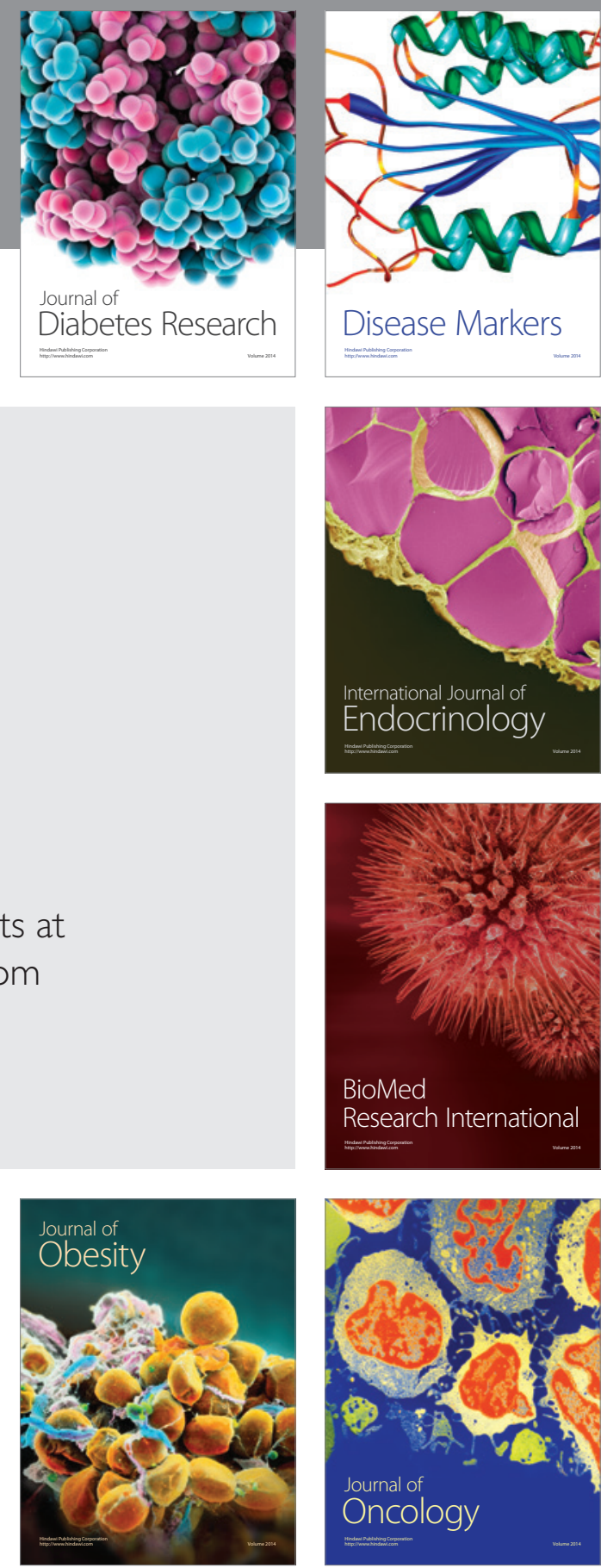

Disease Markers
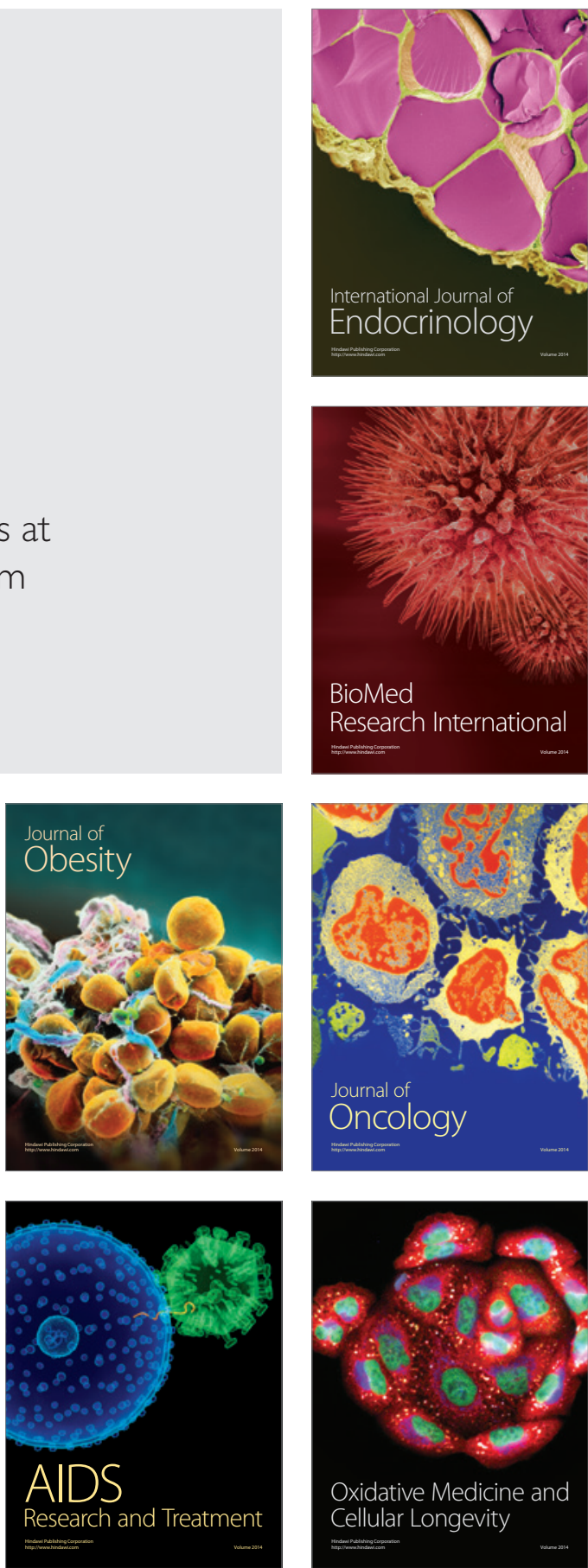